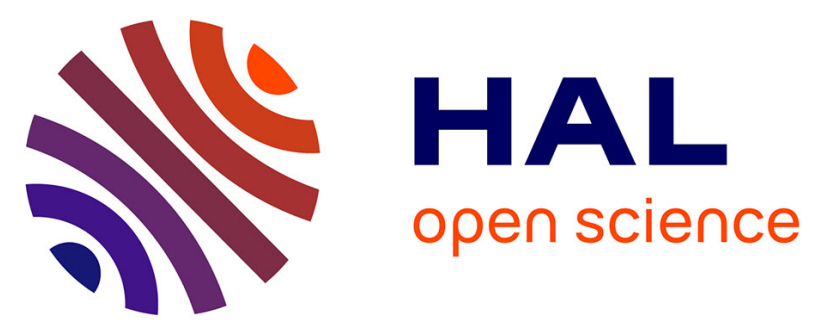

\title{
Environment, economy and community of the upper Angara and middle Yenisei regions: impact of climate change and water reservoir cascades built on the Angara and Yenisei rivers
}

Sergei Gorshkov, Larisa Evseeva, Olga Mochalova, Laurent Touchart, Jean-Louis Ballais, Yves Simone

\section{To cite this version:}

Sergei Gorshkov, Larisa Evseeva, Olga Mochalova, Laurent Touchart, Jean-Louis Ballais, et al.. Environment, economy and community of the upper Angara and middle Yenisei regions: impact of climate change and water reservoir cascades built on the Angara and Yenisei rivers. Polar Record, 2013, 49

(3), pp.254-260. 10.1017/S0032247413000107 . hal-01571439

\section{HAL Id: hal-01571439 \\ https://hal-amu.archives-ouvertes.fr/hal-01571439}

Submitted on 2 Aug 2017

HAL is a multi-disciplinary open access archive for the deposit and dissemination of scientific research documents, whether they are published or not. The documents may come from teaching and research institutions in France or abroad, or from public or private research centers.
L'archive ouverte pluridisciplinaire HAL, est destinée au dépôt et à la diffusion de documents scientifiques de niveau recherche, publiés ou non, émanant des établissements d'enseignement et de recherche français ou étrangers, des laboratoires publics ou privés. 


\section{Environment, economy and community of the upper Angara and middle Yenisei regions: impact of climate change and water reservoir cascades built on the Angara and Yenisei rivers \\ Sergei Gorshkov and Larisa Evseeva \\ Department of Geography, Moscow State University, 1 Leninskie gory, GSP 1, 119991, Moscow, Russia (spgor-smir@yandex.ru)}

\section{Olga Mochalova}

Environmental Initiatives Center, 4/1 Dmytrovskyi Lane, 107031, Moscow, Russia

\section{Laurent Touchart}

Department of Arts, Languages and Humanities, University of Orleans, 10 rue de Tours BP 46527, 45065 Orléans Cedex 2, France

Jean-Louis Ballais

CEGA-UMR 7300 ESPACE, CNRS - University of Aix-Marseille, 29 avenue Robert Schuman, 13621 Aix-en-Provence cedex 1, France

\section{Yves Simone}

Laboratoire Protée EA 3819, University of Sud Toulon-Var, BP 20132, 83957 LA GARDE

Cedex, France

ABSTRACT. This article is dedicated to the aggravation of negative natural and anthropogenous changes in Central Siberia in the Yenisei River geo-system. These changes are probably the result of global warming and climate destabilisation combined with intensified destructive processes in the region.

The last decades were characterised by the following:

1. Growth of mean annual temperatures and change of annual climate structure resulting in extreme weather and hydrologic situations;

2. Large-scale degradation of insular permafrost with corresponding decrease of their water-cut;

3. Dry thunderstorms, fires, forest disease outbreaks became more frequent and abundant in the large areas;

4. Forage resources failures and game animals' depletion in numbers became more frequent;

5. Overgrowing of the Angara and the Yenisei Rivers. Significant drop of spawning sites' reproductive functions;

6. Northern borders of some wild populations' habitats started moving further north;

7. Aggravation of boat traffic conditions and traditional use of natural resources;

8. Taiga lost its fire-suppression and chemical-protection functions almost completely;

9. Some issues have emerged regarding protection of people and domestic animals against natural-endemic diseases as well as predators;

There are good reasons to believe that these processes display an unprecedented environmental crisis of the regional biosphere.

\section{Introduction}

Siberia has experienced changes of climate in the Angara-Yenisei Region in recent years. These changes modify the social and economic life of the region. The most significant changes have been registered in the cold season, when temperature differences between the maximum and minimum figures could be up to $30^{\circ} \mathrm{C}$. Cold weather was frequently followed thaws with temperatures above $0^{\circ} \mathrm{C}$. These phenomena transform the rivers' glacial regimes and increase the risk of accelerated permafrost degradation. Hydro-climatic changes have impact on all different types of land cover units. This impact on the permafrost is of paramount importance. In the first place, permafrost degradation causes comprehensive transformation of stows. The initial climatic response results in such adverse changes as intensification of land- slides, floods, summer droughts and forest fires, as well as decrease in taiga forage resources, growing aggression of predators, etc.

\section{Sources of information and methodology}

Climatic and hydrologic data was provided by the Russian Research Institute of Hydro-Meteorological Information. General data concerning distribution of different types of permafrost in the Middle Yenisei Region was taken from the Geocryological map of the USSR at a scale of 1:2,500,000 in 16 sheets, printed in the Russian and English languages published by Lomonosov Moscow State University, 1996 at the State Cartographic Enterprise in Vinnitsa, Ukraine. The most important observations of the permafrost response to climate warming in 
the middle Yenisei region were performed by the authors in several basins of Yenisei River tributaries between $62^{\circ}$ and $66^{\circ} \mathrm{N}$ during $1996-2011$. The increase of active layer depth, the scope of soil water decrease, changes of the regime of periglacial processes and the modification of permafrost landscapes were taken into consideration.

Information on harm to coniferous forests inflicted by the Siberian silkmoth (Dendrolimus superans sibiricus Tschtv) as well as data on forest fires was received from the Krasnoyarsk Centre for Forest Protection. Decrease of fish and game production, unsustainability of these industries in the region during the 1990s and early 2010 s are among the worst consequences of climate warming. In the middle of the 2000s the 'hungry taiga' term was first used by the local people. It means that years of extremely low yield of berries, mushrooms and nuts became much more common than productive years.

\section{Climate changes}

Climate warming phenomena, especially strong in the boreal zone of Eurasia, were for the first time recorded in the late 1970s. Actual average annual air temperature fluctuations for the Turukhansk Station (observations were carried out during 73 years, 1934 to 2007), the Bakhta Station (53 years, 1955 to 2007), the Bor Station by the Podkamennaya Tunguska River (73 years, 1935 to 2007) and the town of Yeniseisk (108 years, 1900 to 2007) are perfectly well synchronised (Fig. 1). These fluctuations have correlation ratios (r), equal to 0.934 for Yeniseisk and Bor (r E, Bor), 0.985 for Bor and Bakhta (r Bor, Bach) and 0.941 for Bakhta and Yeniseisk (r Bach, E).

The general trend of air temperature changes was reconstructed for the period of 1900-2007 using these correlation ratios for the stations of Yeniseisk, Bor (Podkamennaya Tunguska), Bakhta, and Turukhansk. It indicates an upward trend of average air temperature at these stations. During the study period (108 years) the absolute warming effect amounted to $2.5^{\circ} \mathrm{C}$ in Yeniseisk, $1.6^{\circ} \mathrm{C}$ in Bor and Bakhta, and $1.1^{\circ} \mathrm{C}$ in Turukhansk (Fig. 2). 1974 was the coldest year. The warmest one was 1995. The process of warming was more intense in the southern part of the area and less pronounced in the north. The decade averages were $0.23^{\circ} \mathrm{C}$ in Yeniseisk, $0.15^{\circ} \mathrm{C}$ in Bor and Bakhta and $0.10^{\circ} \mathrm{C}$ in Turukhansk.

The integral curves of mean annual air temperature for all these stations show definite cooling in the second half of the twentieth century (since mid-1950s until late 1970s-early 1980s). In the study area (Mochalova 2003: 22-37) a stable increase of mean annual temperature began in the 1980s. It is interesting that all integral curves were flat within the period of 1994-2000, after which there came a second wave of warming. The start of permafrost degradation in the insular distribution subzone corresponds to this period. Thus, heat accumulation that took place due to positive deviations from the mean annual temperature during the period of 1980 to mid

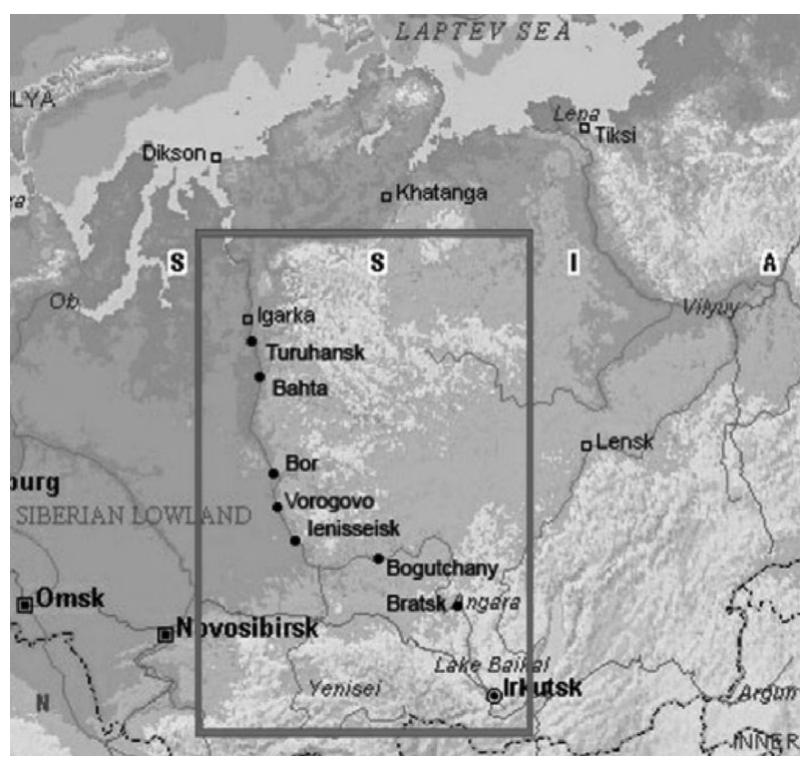

Fig.1. Research area.

1990s was sufficient to initiate the degradation processes (Fig. 3).

The most significant warming occurred in winters. 1974 was cold, the minimum monthly average air temperatures of January were minus $35.1^{\circ} \mathrm{C}$ in Bor and minus $35.5^{\circ} \mathrm{C}$ in Bakhta. In the warm 1995 these indicators were minus $17.8^{\circ} \mathrm{C}$ and minus $18.0^{\circ} \mathrm{C}$, respectively. The difference in average July temperatures for the same two years did not exceed $1.7^{\circ} \mathrm{C}$ in Bor and $2.5^{\circ} \mathrm{C}$ in Bakhta.

Temperature fluctuations can be explained sufficiently by atmospheric circulation in the middle reaches of the Yenisei River and the basins of the lower Tunguska and Podkamennaya Tunguska Rivers. Low temperatures during the cold period are related to the settling of a stable western branch of the Asian anticyclone in this region, with formation of winter inversions and severe cooling of the surface soil just slightly covered with snow. Weakening of the Asian anticyclone and a shift of its western spur usually to the southeast gives way to less stable and warmer anticyclones of local origin or those coming from the west, southwest or northwest. In the middle of winter they can change the air temperature considerably. This happened in 1995 when the Asian anticyclone was replaced by the anticyclone that came from the west.

Data for the boreal sector of the central Siberian cryolithozone is highly representative for understanding of changes in nature and thus in the economy and social spheres. This data is confirmed by very close average annual temperature oscillations in the middle Angara and the Yenisei part of central Siberia (Fig. 4). Fairly high correlation $(r=0,85)$ of curves representing changes in mean annual air temperature and the similarity of trends for the stations of the Bratsk Reservoir and those in the Yenisei Siberia some $1000 \mathrm{~km}$ away are the evidence of interrelation between temperature regime changes and 


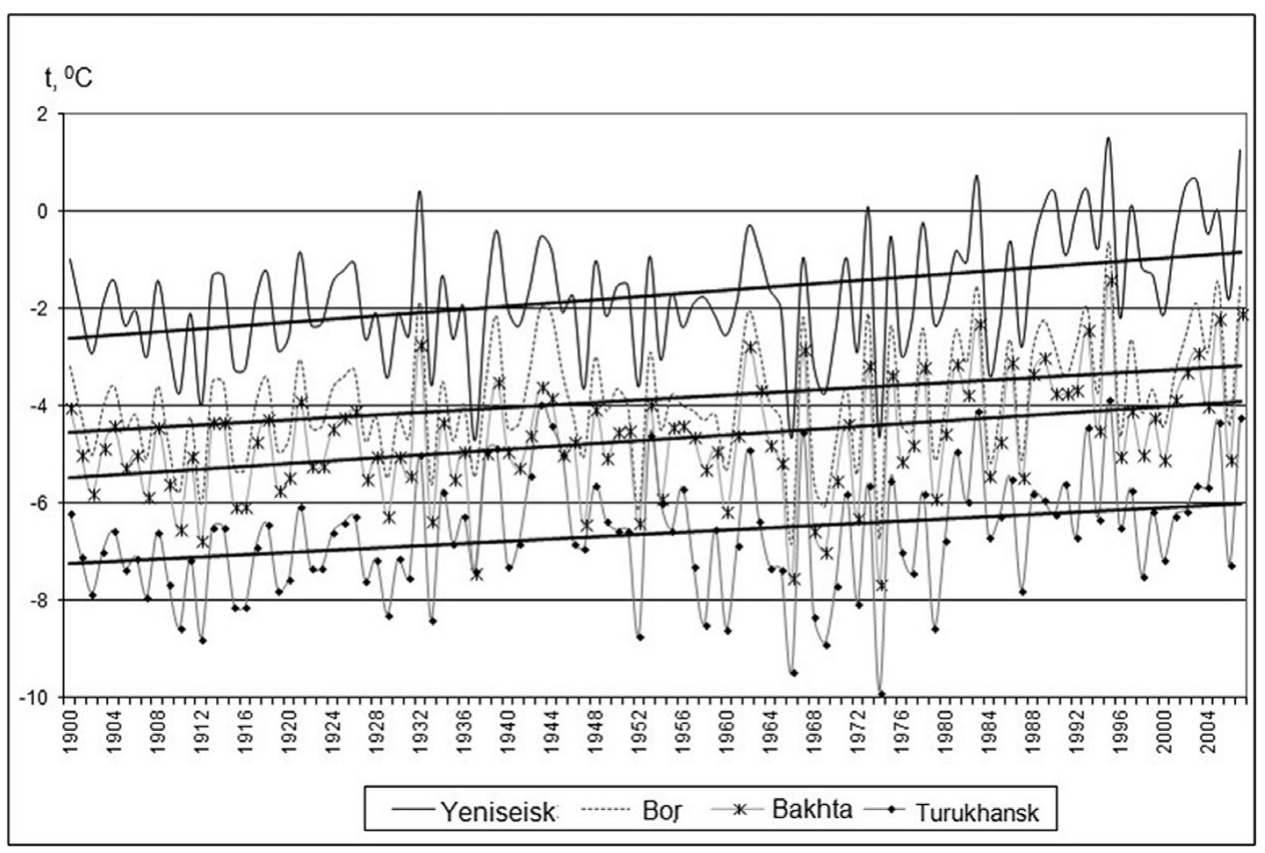

Fig. 2. Mean annual air temperatures for Yeniseisk, Bor, Bachta and Turuhansk stations in 1900-2007 and the general trend of change.

global warming. The regional impact of the Bratsk Reservoir on temperature changes in the coastal areas is overlapped by much more profound global processes.

\section{Hydrological changes}

The average annual water flow rates (Qyear, $\mathrm{m}^{3} / \mathrm{sec}$ ) and flow regulation (Qmax/Qmin) of Angara, Yenisei, Lower Tunguska and Podkamennya Tunguska Rivers for different periods are as follows (Table 1):
It is illustrative that during the current global warming period which started at the end of the 1970s in succession to a cooling period, the flow in the lower reaches of the Yenisei River (the Igarka hydrometric station) increased compared to the period before the water reservoir construction. This rise took place due to the noticeable flow increase in the northern part of the Yenisei River basin; this follows from the annual average water flow rates of the Lower Tunguska and Podkamennaya Tunguska

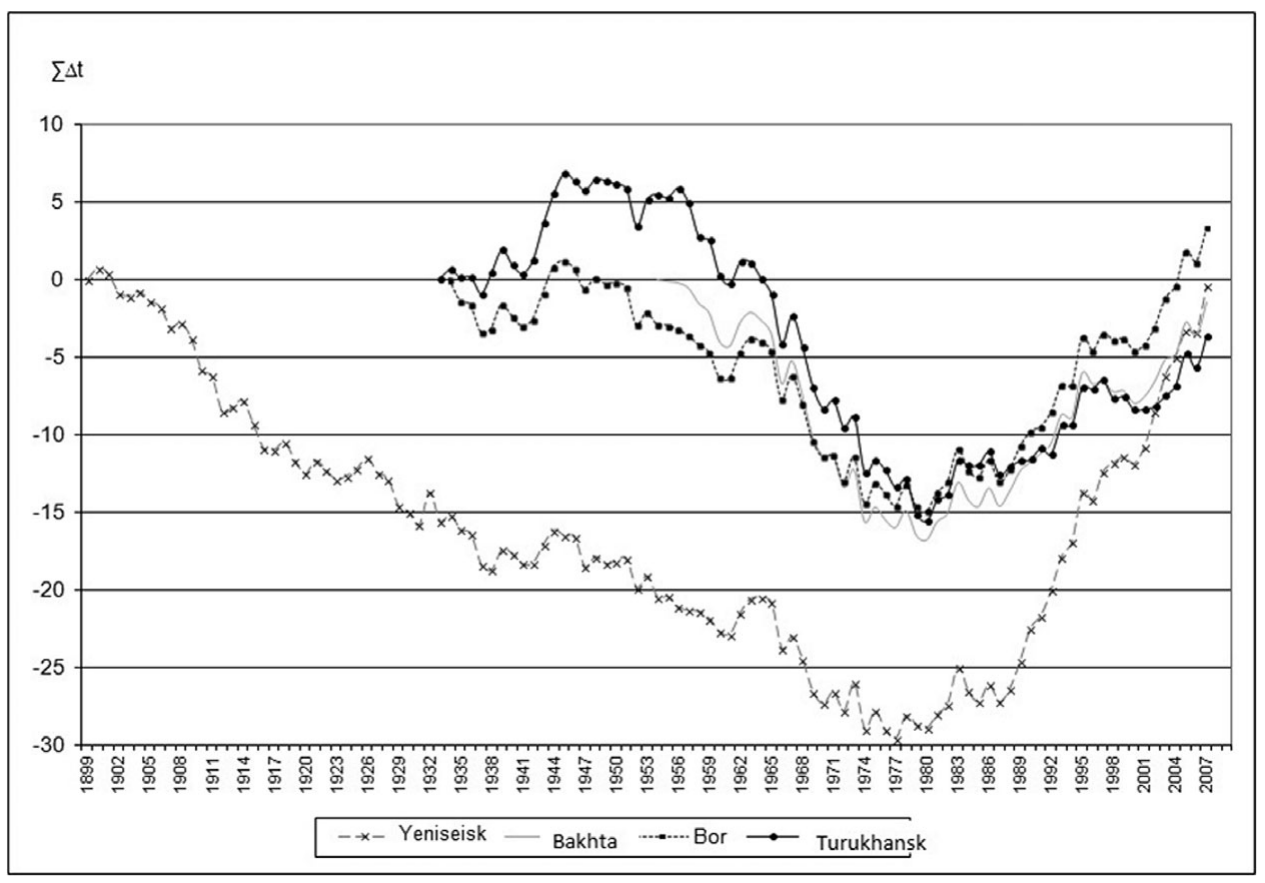

Fig. 3. Integral curves of the sums of annual mean temperature deviations from the norm for Yeniseisk, Bor, Bachta and Turuhansk stations. 


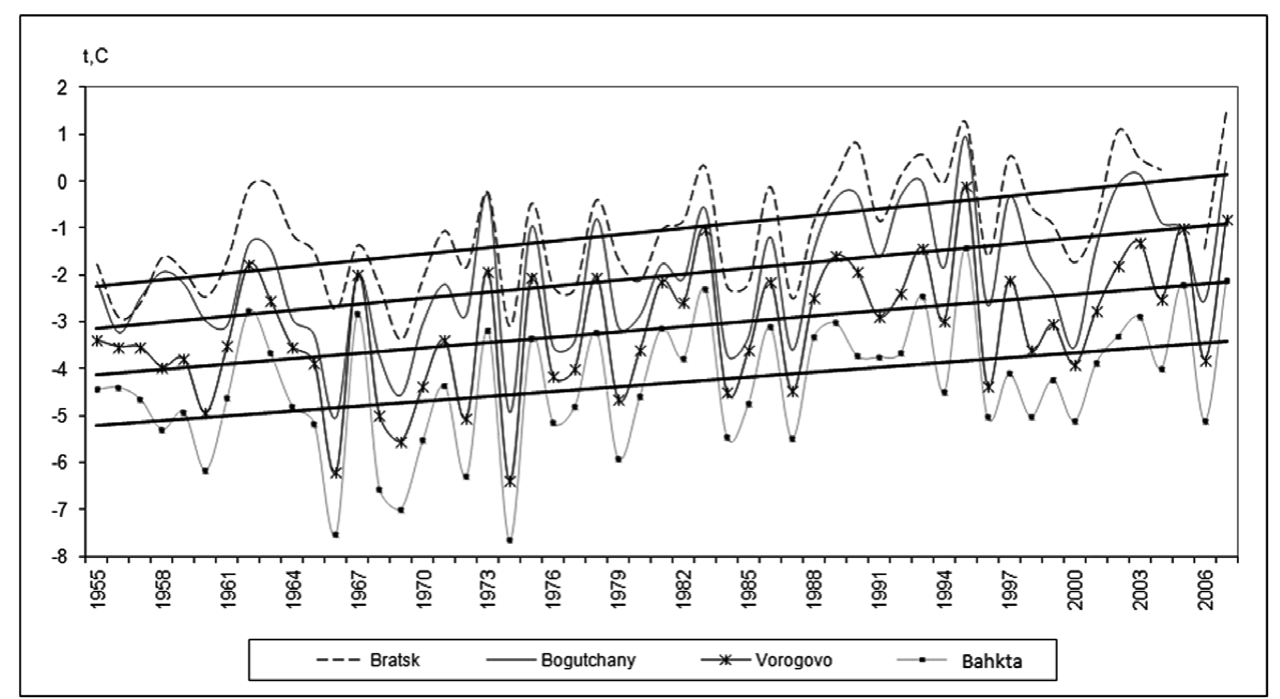

Fig. 4. Mean annual air temperatures for Bratsk, Bogutchany, Vorogovo and Bahta stations in 1955-2007 and the general trend of change.

Rivers. Meanwhile, the Yenisei River flow rate in its middle reaches and the Angara River flow rate (hydrostations of Yeniseisk and Boguchany) have not reached the natural values of 1936-1955. This can indicate additional water losses due to evaporation increase that takes place in the southern part of the Angara-Yenisei River basin, particularly from water reservoirs during the current climate warming period. In addition, some data suggests a certain decrease in mean annual precipitation in the forest-steppe zone.

\section{Impact of climate change}

\section{Permafrost}

The following processes can be identified as probable responses to climate warming in the insular and discontinuous permafrost subzones: 1) increase of the active layer depth and intensification of solifluction processes; 2) local replacement of solifluction processes by landslide mass movement in the areas of active river erosion; 3 ) frequent falling of trees with a creeping root system. Usually it happens in the areas where the depth of viscousplastic hydromorphic clays is about $1.5 \mathrm{~m}$ or more; 4) existence of trees with bent trunks and vertical tops; 5) improvement of drainage on top surfaces and adjoined gentle slopes (water disappears from ruptures-windows; it is often absent in fissures-ruptures); 6) increasing num- bers of stone blocks in unstable positions on the surface of kurums ('stone seas') as well as the spread of reindeer moss patches (both in size and number); 7) discharge of ground rills under a block cover of kurums; 8) noticeable warming in underground kurum space after a decrease in water supply; 9) possible lowering of the permafrost table in kurum stows; 10) intensification of thermokarst processes; 11) wide development of long-frozen soil which can indicate recent permafrost degradation in places; 12) occurrence of young fir-tree stands within burnt areas previously covered with different coniferous species.

\section{Changing rivers}

Large rivers with no dams become more dangerous for settlements. Sudden warming in the beginning of spring usually causes high and even catastrophic local ice-dam floods. For the Yenisei and Angara Rivers a more complicated picture is observed. Compared to the past, the regime of these rivers altered under the impact of climate change and the operation of hydropower plant cascades. There are several large-scale negative processes. One of them is the catastrophic local ice-dam floods. These phenomena became more frequent because of loss of the natural bottom erosion, especially during spring floods in the lower reaches of the Krasnoyarsk hydropower station reservoir as well as in the same part of the Ust-Ilimsk one. Several settlements on the banks

Table 1.

\begin{tabular}{|c|c|c|c|c|c|c|}
\hline \multirow{2}{*}{$\begin{array}{l}\text { Periods } \\
\text { Characteristics Hydrometric } \\
\text { station }\end{array}$} & \multicolumn{2}{|c|}{$1936-1955$} & \multirow{2}{*}{$\begin{array}{l}1956-1975 \\
Q_{\text {year }}, \mathrm{m}^{3} / \mathrm{sec}\end{array}$} & \multicolumn{2}{|c|}{ 1976-2000 } & \multirow{2}{*}{$\begin{array}{l}\text { 1936-2000 } \\
\mathrm{Q}_{\text {year }}, \mathrm{m}^{3} / \mathrm{sec}\end{array}$} \\
\hline & $Q_{\text {year }}, \mathrm{m}^{3} / \mathrm{sec}$ & $Q_{\max } / Q_{\min }$ & & $\mathrm{Q}_{\text {year }}, \mathrm{m}^{3} / \mathrm{sec}$ & $Q_{\max } / Q_{\min }$ & \\
\hline Angara-Boguchany & 3720 & 3.4 & 3260 & 3570 & 2.0 & 3520 \\
\hline Yenisei-Yeniseisk & 8120 & 7.1 & 7560 & 7490 & 2.7 & 7730 \\
\hline Yenisei-Igarka & 18300 & 19.5 & 18000 & 18800 & 10.4 & 18395 \\
\hline L.Tunguska-Bolshoy Porog & 3312 & - & 3500 & 3628 & - & 3490 \\
\hline P. Tunguska-Kuz'movka & 1477 & - & 1641 & 1619 & - & 1587 \\
\hline
\end{tabular}


of the Angara and Yenisei Rivers suffered from ice-dam floods (Ovchinnikov and others 1999: 254). For example, houses in the Vorogovo Settlement were partly destroyed by the river ice in the spring of 1999.

\section{Algae overgrowing in the Yenisei middle reaches}

During 1960-1970s two huge hydropower plants were constructed in the upper reaches of the Yenisei. In the past the river had high swift floods every spring. Silt had accumulated in the interior floodplain while sand, gravel, pebbles, and boulders formed the river channel. Since the end of 1970s the Yenisei River as well as the Angara River became completely regulated. Both rivers lost their natural floods.

Silt in the Yenisei River is polluted with radionuclides about $100 \mathrm{~km}$ to the north from Krasnoyarsk and further on. These sediments accumulated in many parts of the channel and on the lower floodplain. Silting of shallow water bottom, which lasts longer than in the previous warm periods, and the absence of natural 'cleaning' floods have already led to algae overgrowing in the Yenisei middle reaches. The northern limit of the algae zone is $61^{\circ} 20^{\prime} \mathrm{N}$. This point named the Osinovskiy Rapid is located about $60 \mathrm{~km}$ to the south of the Podkamennaya Tunguska River mouth (Gorshkov 2004: 10-12).

Considerable deterioration of floodplain lands and spawning areas took place as well as adverse changes in the composition of ichthyofauna. Bream has replaced such valuable fish species as sturgeon and sterlet in the zone of algae expansion.

Local people call bream a waste fish while sturgeon and sterlet are traditionally considered as red species. People of the Yenisei bank settlements experience considerable losses because their survival depends mostly on fishing. Red fish are of primary importance for subsistence and income for the majority of local people.

\section{Forest fires}

Forest fires became more frequent although the anthropogenic pressure on the taiga decreased significantly. If a dry hot period continues for about one month or longer during the summer, numerous forest fires are inevitable. People working in the taiga confirm that the main reason for forest fires is dry thunderstorms. It is almost impossible to put out a large forest fire if the area is situated far from a settlement. Navigation on big rivers is often affected by heavy smoke resulting from forest fires. During the summer of 2003 the number of fires reached over 1100 within Krasnoyarsk Krai.

An essential factor that promotes forest fire expansion is the decrease of water content in soils and surface cover within the areas where the permafrost table becomes lower due to its degradation. Another factor is the increasing area of dead coniferous forests due to the growing pest activity. An indirect reason is the inadequate finance and poor technical support available especially by helicopters and light aeroplanes.

\section{Wildlife productivity decrease}

Yields of mushrooms, berries, and nuts decreased very significantly because of climatic destabilisation. In the period of plant blooming deep frosts that occur after the spring warming reduce berry formation in taiga forests. More frequent summer droughts also affect the yield of berries, as well as the production of conifer seeds including nuts of Siberian pine (Pinus sibirica L.). Cowberry (Vaccinium vitis idaea L.), bilberry (Vaccinium myrtillus L.), bog bilberry (Vaccinium uliginosum L.), honeysuckle (Lonicera coerulea L.), black currant (Ribes nigrum L.), red currant (Ribes rubrum L.), bird cherry (Padus avium L.) are the most important berries for animal survival and the traditional economy. A good nut yield is of significant, direct and indirect, importance for different wildlife populations, particularly brown bear (Ursus arctos L.), squirrel (Sciurus vulgaris L.), and chipmunk (Eufamias sibiricus Laxm.). Unfortunately, small harvests of Siberian pine nuts might soon become a rule rather than an exception.

In the 1990s and early 2000s low production years became predominant in the Podkamennaya Tunguska lower reaches. At the same time dry thunderstorms caused many forest fires.

For the last three years very poor yields of fir and spruce seeds have caused a significant decrease in the numbers of squirrels in several districts of Central Siberia. Then it was ordinary to meet only one squirrel per 10-km in taiga of the Yeniseisk District.

The black-cock (Lyrurus fefrix L.) population has become especially low due to the poor yield of birch seeds and berries. Changing their eating habits, blackcocks now eat fragments of small branches of hardwood trees and bushes as well as the seeds of coniferous trees. In the beginning of spring, forest fires often kill eggs as well as helpless nestlings. Besides, eggs are often damaged by strong frosts. The situation with the black-cock population is not an exception. The numbers of capercaililes (Tefrao urogallus L.) and hazel-grouses (Tetrastes bonasia L.) decreased significantly as well. The increase of bird-predator populations is named as one of the other reasons for the drop of black-cock numbers.

\section{Depredators}

A catastrophic expansion of the Siberian silkmoth happened during the hot summers of 1994, 1995, 1997 and 1998, when one hundred or more forest fires were registered in the Yeniseisk district alone. The parasites killed mostly fir forests and partly Siberian pine forests. The total affected area accounted for about $5000 \mathrm{~km}^{2}$ in the Angara lower reaches and the adjacent areas in the Yenisei middle reaches. If a dead forest is not cut during 2-3 years after the beginning of Siberian silkmoth attack, it might be used only as fire wood because trunks will be destroyed by other pests. Dead forest is most dangerous as a source of parasite distribution and as an area of possible fire expansion. 


\section{Broadening and shortening of animal habitats}

A shift from the south zone into the subzone of middle taiga (to about $62^{\circ} \mathrm{N}$ ) has been recorded for the encephalitis-carrying tick (Ixodes persulcatus). During the last 25 years the northern limit of the range of this tick moved approximately $250 \mathrm{~km}$ to the north. Many insects that were known from the south taiga or the foreststeppe zone have been found and in the Podkamennaya Tunguska lower reaches and the Yenisei middle reaches, in the Central Siberian State Biosphere Reserve in particular. In connection with permafrost degradation within many kurums ('stone seas'), the coneys (Ochotona alpine Pall.) left that habitat and concentrated in the adjacent valley bottoms.

\section{Problems of the Kets traditional economy}

Vladimir Tyganov, former head of the Sulomay Settlement administration, stated the following, 'In 1950-60s the Kets caught a lot of fish, hunted elks for meat, raised cows and planted potatoes, collected nuts, mushrooms and berries. Hunters got about two hundred skins of sables and even more of squirrels and the Government used to buy all of this. The small enterprises, so-called promkhoz, were active in every settlement. Some Kets were engaged in the reindeer breeding' (Baskin: 2009: 284).

Now the resources for hunting and fishing are significantly exhausted. The main reason for this is the deterioration of the fodder base of the ecosystems in the middle taiga subzone. An exception is the fishery, which decreased several times because of overfishing. Yields of mushrooms, berries and nuts decreased considerably because of climatic destabilisation. The impacts of short strong frosts during the blooming period, immediately followed by dry heat are also dangerous for a future yield of taiga plants. In the beginning of the 2001 winter a thin snow cover promoted the formation of thick river ice. The early spring was too warm and the spring flood with ice run formed a high ice dam in the narrow part of the Podkamennaya Tunguska River valley. The destruction of this dam led to a catastrophic flood of $23.5 \mathrm{~m}$ above the low-water level. Floating ice destroyed the majority of houses in the Sulomay Settlement. Ice also cut many trees on both river banks. A new settlement was built higher on the river banks. Now Sulomay has satellite communication but the income of the majority of native families is not sufficient for survival. They receive some financial support from the Baikit District administration, which is part of the Evenki Autonomous Area. The huge oil deposit named Kuymbe was discovered in the 1980s near Baikit. The Ket people continue fishing, hunting elks and forest reindeers, collecting berries, mushrooms, nuts and hunting for sable, squirrel, and brown bear just as they did in the past. Unfortunately many of them often do not have money to buy enough food even for their children. In Central Siberia the total number of the Kets is about eight hundred people. One fifth of them live in Sulomay.

\section{Forestry economy}

The filling of the Irkutsk, Bratsk and Ust'-Ilimsk reservoirs on the Angara River, as well as the SayanoShushenskoye and Krasnoyarskoye man-made lakes on the Yenisei River has led to a drop of water level in these rivers during abnormally warm and dry years. This may lead to the decrease of navigation time and timber transportation period on the Angara River which is used for these purposes and delivers timber from many settlements to the wood processing plants in two towns (Lesosibirsk and Novoyeniseisk). The welfare of local people completely depends on the uninterrupted operation of the wood processing industry.

On 1 August 2003, Nikolay Nepeivoda, the chief engineer of Saw-woodworking plant No. 1 in Lesosibirsk, gave a short interview. He said,

In the Angara River lower reaches there is a real risk of navigation period shortening since August 15 till the end of shipping season. In July 2003 the State Water Service notified everyone in advance that water flow in the Angara lower reaches might be significantly decreased as it was necessary to keep and, if possible, rise water level in the Bratsk and Ust'-Ilimsk Reservoirs. Impossibility of transporting $400000 \mathrm{~m}^{3}$ of round wood to the plants in Lesosibirsk and Novoyeniseisk will cause interruptions of wood processing activities and lead to temporary unemployment in the mentioned towns and in the Angara River basin settlements that provide the industry with log wood. Since there are no chances of bringing petroleum, oil and lubricants in these settlements, round wood will not be transported out from the felling sites in taiga and will decay. People of the whole region working in the forestry industry will not receive their salaries for several months. That will lead to a crisis in municipal, commercial and educational spheres of the region. CEO's of saw-wood processing plants of Lesosibirsk and Novoyeniseisk appealed to the Administration of the Krasnoyarsk Krai with a letter asking to find a way of cancelling the decision on the water flow decrease in the Angara lower reaches (N. Nepeivoda, personal communication, 1 August 2003).

\section{Ecological shock in the biosphere}

If we look at the whole boreal forest belt in the northern hemisphere, our Central Siberian case study demonstrates a rule rather than an exception.

It is known from many regions that the biosphere has responded to global climate warming by destabilisation of the quasi-steady state that was typical for cooler climatic conditions during 1950-1970s. The destabilisation is expressed through: 1) the rise of annual mean temperatures, changes in the annual structure of climate and more frequent weather and hydrological extremes; 2) the start of wide degradation of the insular and discontinuous permafrost within the majority of permafrost landscape types and related decrease of their water content; 3 ) the increased frequency of dry thunderstorms, forest fires, 
tundra and other geographical zones, pest outbursts over vast areas, and poor yields of forage resources; 4) the decrease of some animal populations because of their habitat reduction, adverse changes in the composition of ichthyofauna, expansion of several animal and plant species especially in the temperate and cold geographical zones of the northern hemisphere. The bulk of evidence suggests that the present-day situation can be called a geoecological shock in the biosphere (in accordance with the understanding of this term by V.I. Vernadsky (Vernadsky 1998: 14-19).

\section{Adaptation to the consequences of climate warming as the major present-day task}

Our civilization is not able to stop global warming in the forthcoming decades. Therefore the problem of adaptation associated with climate change may be more urgent than IPCC ideas and conclusions suggest.

It is necessary to create a conception of the natural and natural-anthropogenic systems transformation under global warming, and to find ways of mitigating or even eliminating the negative consequences in these systems. The basic concept should include: 1) geographical demarcation, 2) classification of geographical regions based on the evaluation of their ecological potential and degree of destabilisation of natural and natural-anthropogenic systems, 3) detection of correlation between the parameters of climatic, hydrological, geocryologic and geomorphologic events, on the one hand, and the intensity of negative processes in biological components of the systems, on the other hand. This approach might allow forecasting some future adverse events and mitigating or eliminating their consequences.

\section{References}

Baskin, L.M. 2009. North reindeer. Moscow: KMK comradeship of scientific editions.

Gorshkov, S.P. 2004.Global warming impact on nature, economy and society in central Siberia. In: Russian national workshop on research related to the international human dimensions programme on global environmental change. Zvenigorod: Press of Russian Agricultural Academia (Proceedings 10-12): 194-203.

Mochalova, O.I. 2003. Climatic conditions and landscape changes in the Angara-Yenisei Region. In: Climate, permafrost and landscapes of the middle Yenisei Region. Moscow: Lomonosov Moscow State University, Faculty of Geography: 22-37.

Ovchinnikov, G.I., S.Kh., Pavlov, and Y.B. Trzhcisky. 1999. Izmenenie geologicheskoi sredy $v$ zonahk vliyaniia angaroeneseiskihk vodohkranilits [Change of geological environment in the Angaro-Yenisei HPP's zone of influence]. Novosibirsk: Science, Siberian branch.

Vernadsky, V.I. 1998. The biosphere. New York: Copernicus, Springer Verlag: 14-19. 